------- Original Message --------

Subject: RE: your copyedited manuscript for online Slavic Review forum

Date: 09.07.2018 18:57

From: "Tartakovsky, Dmitry" <tartakov@illinois.edu>

To: Agnieszka Pasieka <agnieszka.pasieka@univie.ac.at>

Dear Agnieszka,

This email is to verify that an errata section will be printed in the Fall 2018 Slavic Review, 77:3, stating:

In the 2017 Special Online Issue of Slavic Review, in the Critical Forum on Global Populisms, the article titled "Taking Far-Right Claims Seriously and Literally: Anthropology and the Study of Right-Wing Radicalism," pages S19-S29, by Agnieszka Pasieka, should have carried an attribution stating the following: "This project has received funding from the European Union's Horizon 2020 research and innovation programme under the Marie Sklodowska-Curie grant agreement No 656377."

Sincerely, Dmitry

Dmitry Tartakovsky, PhD

Managing Editor,_Slavic Review [1] 1207 W. Oregon St.

Urbana, IL 61801

217-300-0293

tartakov@illinois.edu

Links:

[1] http://www.slavicreview.illinois.edu/ 


\title{
Taking Far-Right Claims Seriously and Literally: Anthropology and the Study of Right-Wing Radicalism
}

\author{
Agnieszka Pasieka
}

That we are witnessing the rise of right-wing populism and the growth of farright movements on a global scale is likely obvious to most followers of the mass media. The debates on how to understand these phenomena and make sense of what is being perceived as a sweeping change of the socio-political landscape are no longer confined to academic circles, becoming a frequently and widely discussed subject by the public. Apart from perhaps slightly wornout yet still relevant arguments identifying "globalization," "post-industrialization" and "disappointment with political elites" as the main culprits of current developments, commentators have begun to take a wider perspective, trying to situate the phenomena observed "at home" in broader historical and geo-political contexts. In doing so, numerous journalists have pointed to the problem of a resurgent "nationalist international," with troubling parallels to interwar (mostly fascist) predecessors, in order to indicate the most worrisome aspects of new (or "reborn") transnational alliances of right-wing radicals. Others have drawn comfort from comparisons to the 1930s.

Let us consider a few examples. A recent issue of The Economist discusses the rise of far-right parties across the world and strives to place the new "league of nationalists" into historical context, but finds the comparison with the 1930s to be fatuous, given the present lack of a "truly totalitarian nationalism." In criticizing cosmopolitan elites for overlooking that national sentiments are important, the weekly nonetheless places hope in an increasing number of educated people, who are "typically cosmopolitan in instinct."1 In a similar vein, The Washington Post suggests that contemporary "multicultural cities" are a bulwark against the dangerous wave of right-wing nationalism. We read there that: "Increasingly, nation-states look parochial and backward, and cities are actually cosmopolitan ..."2

In turn, $B B C$ reports that even if worrying now, far-right influences will be soon weakened due to people's increasing attachment to regional (rather than national) identities, which will lead to a substitution of political identities with cultural ones. ${ }^{3}$ Italian La Repubblica notes the new far-right alliances, stressing that the avalanche of populism no longer comes only from

1. "League of Nationalists," The Economist, November 19, 2016, at www.economist. com/news/international/21710276-all-around-world-nationalists-are-gaining-groundwhy-league-nationalists (last accessed May 2, 2017).

2. Ishaan Tharoor, "The West's Major Cities Are a Bulwark Against the Tide of Rightwing Nationalism,” The Washington Post, November 22, 2016, at www.washingtonpost. com/news/worldviews/wp/2016/11/22/the-wests-major-cities-are-the-best-defenseagainst-the-tide-of-right-wing-nationalism/?utm_term $=.9 c 3 c 3853 \mathrm{c} 3 \mathrm{ef}$ (last accessed May 2, 2017).

3. Joerg Schulze, “The Far Right: A Nationalist International?,” $B B C$, at www.bbc. co.uk/worldservice/theneweurope/wk19.htm (last accessed May 2, 2017).

Slavic Review 76, no. S1 (2017)

(C) 2017 Association for Slavic, East European, and Eurasian Studies

doi: $10.1017 /$ slr.2017.154 
eastern Europe. ${ }^{4}$ The Guardian concurs with this observation, yet also adds that authoritarianism, fascism, and racism in the eastern Europe should "alarm us more" (than analogous developments in the west) due to easterners' "low levels of democratic consciousness and traditions" and because in the east these phenomena are "not driven by the normal driver of extremism which is economic failure." 5

I am mentioning these few instances not only because I find it crucial to emphasize particular implications of the fact that the phenomena we are debating within academic circles have become a part of a wider imaginary and broader conversations. I am bringing them up first and foremost because they provide a backdrop which allows us to see in a full light what scholars may and should contribute to this-by now public-debate on the far-right scene and its actors.

As an anthropologist and researcher studying far-right movements and, last but not least, as an eastern European, I cannot but object to many of the statements quoted above and express doubts about the proposed urban/rural, educated/non-educated, and western/eastern Europe schemes that are to correspond, respectively, with cosmopolitan openness and nationalistic narrowmindedness. Similarly, I find the proposed understanding of historical context as an unchangeable matrix of events and symbols to be misleading. I hold a view of cultural identities as less prone to exclusion and boundedness than national ones to be simply wrong. By no means, however, is this critique of journalistic explanations supposed to suggest anthropologists' superiority. Quite the contrary, in what follows I would like to reflect on why anthropologists' and other social scientists' voices aren't more prominent in explaining the ongoing developments as well as to suggest in what way they could be. Anthropological methodology-long-term fieldwork, intense engagement with research participants, attempts to articulate "native points of view," as well as a contextual explication of research participants' concepts and discoursescould complement macro-level and less "actors-centered" studies. With this in mind, in the following I aim to identify some prerequisites of a serious and thorough engagement with the subject of the far right from the social-scientific perspective; an engagement that might not only help us to partake more actively in current debates but also to challenge some flawed assumptions. My discussion is organized in terms of three themes, which refer to methodological, conceptual, and ethical aspects of the research on the far right.

\section{Taking Transnationalism Seriously}

As mentioned above, inter- or transnational cooperation among far-right groups is by now a phenomenon quite widely recognized and commented on

4. Andrea Bonanni, "La Valanga Populista Minaccia la Vecchia Europa," La Repubblica, September 5, 2016, at www.repubblica.it/esteri/2016/09/05/news/la valanga_populista_minaccia_la_vecchia_europa-147203010/ (last accessed May 2, 2017).

5. Paul Mason, "The Far Right is Weaselling into the Mainstream, Dressed up in Suits,” The Guardian, May 2, 2016 at www.theguardian.com/commentisfree/2016/may/02/ far-right-europe-austria-democratic-right-elect-cleaned-up-fascist-president-suspendcountry-from-eu (last accessed May 2, 2017). My emphasis. 
(within and outside of academia), oftentimes under catchy labels of "league of nationalists," "authoritarian international" or "nationalist international."6 Some of the terms used clearly refer to analogical developments on the left in the past, thereby suggesting certain parallels but also implying that the right has begun to adopt tactics "traditionally" embraced by their political opponents. Yet, does the use of such descriptors truly correspond with what is supposedly discussed? To put it differently: is it really a transnational dimension that is being explored in current discussions on far-right growth across different countries?

Before discussing the particular case of the far right, it is important to note why and in what ways "transnationalism" has become a popular, even "trendy," notion in numerous disciplines. In general terms, studies of transnationalism are meant to supplement research on internationalism, traditionally focusing on relations and peaceful cooperation between nation-states by bringing to the fore the increased connectivity among people and networks transcending nation-states borders. ${ }^{7}$ In anthropology, the transnational approach was popularized by scholars exploring new facets of globalization as well as by scholars studying migratory networks, exemplified in research on "transnational social spaces." 8 Similar tendencies could have been observed in kindred disciplines, especially in history with its increased focus on cultural transfers, networks and "entangled histories." It is also in history that the "dark side" of transnationalism has been more thoroughly addressed. ${ }^{9}$ Consequently, transnationalism is today one of those terms which are being used quite freely and in all possible manners, in discussions about transnationalism "from below" and "from above," "globalization" and "glocalization," "cosmopolitanism" and "new indigeneity."

6. It might be worth adding that the borderline between academic/non-academic discussions is increasingly blurred, given the growing amount of scholarly exposure in non-academic journals and other media.

7. However, it should be noted that in certain disciplinary contexts, such as history, the emphasis on the transnational actually preceded the recent interest in transnationalism.

8. E.g. Arjun Appadurai, Modernity At Large: Cultural Dimensions of Globalization (Minneapolis, 1996); Ulf Hannerz, Transnational Connections: Culture, People, Places (London, 1996); Michel-Rolph Trouillot, Global Transformations: Anthropology and the Modern World (New York, 2003); Shalini Randeria, "Entangled Histories of Uneven Modernities: Civil Society, Case Councils, and Legal Pluralism in Postcolonial India,” in Heinz-Gerhard Haupt and Jürgen Kocka, eds., Comparative and Transnational History: Central European Approaches and New Perspectives, (New York, 2009), 77-104; Peggy Levitt and Nina Glick Schiller, "Conceptualizing simultaneity: A Transnational Social Field Perspective on Society," International Migration Review 38, no. 3, (Fall 2004): 1002-39.

9. For approaches to transnationalism in history, see, Philipp Ther, "Comparisons, Cultural Transfers and the Study of Networks: Towards a Transnational History of Europe," in Haupt and Kocka, Comparative and Transnational History, 204-25; Jürgen Kocka, "Comparison and Beyond," History and Theory 42, no. 1 (February 2003): 39-44; Patricia Clavin, "Defining Transnationalism," Contemporary European History 14, no. 4 (November 2005): 421-39. For the discussions on the "dark sides of transnationalism," see Kiran Klaus Patel and Sven Reichardt, "The Dark Side of Transnationalism: Social Engineering and Nazism, 1930s-40s," Journal of Contemporary History 51, no. 1 (January 2016): 3-21. 
Numerous scholars were quick to point out the shortcomings of the transnational approach. Authors of case-studies relevant for this article's topic rightly note that although claiming the term, many analysts end up doing comparative rather than transnational research or, on the contrary, they are so focused on the transnational dimension that they lose sight of particular national contexts. ${ }^{10}$ Research on current developments also reveals similar tendencies through its comparison of far-right parties in different countries by taking into account their similarities and differences, such as electoral programs and political strategies, but not necessarily actual exchanges and connections. Moreover, many such studies are carried out in a post-cold war perspective, starting with an assumption that it is necessary to analyze separately developments in post-communist eastern and western Europe. ${ }^{11}$ Starting from this analytical-geopolitical scheme, such an approach precludes observation of certain common grounds responsible for the upsurge of the far right and its important transnational component, for instance, labor migration from east to west. Likewise, while rightly emphasizing the weight of postwar developments in shaping the present-day far-right scene, our postcold war vantage point neglects the fact that post-communist transition and (re)integration into European structures differed substantially across eastern and southern Europe and, more generally, often led to a perpetuation and simplification of eastern Europe's otherness. It is here that the value of anthropological approaches, which long cautioned against rushed assumptions about eastern European "distinctiveness" and "divergence" from what is considered a "normal" path, is most evident.

Last but not least, research on transnational far-right activism tends to be centered on-no doubt very important but not sufficient-an analysis of exchanges via the internet and borrowing on the level of symbols and discursive strategies. ${ }^{12}$ While not completely disconnected from the analysis of the actors engaged in such exchanges or the carriers/creators of symbols, such analyses often overlook or downplay the fact that transnationalism "is first and foremost about the people: the social space they inhabit, the networks they form and the ideas they exchange."13

10. See: Federico Finchelstein, Transatlantic Fascism: Ideology, Violence, and the Sacred in Argentina and Italy, 1919-1945(Durham, 2010); Andrea Mammone, Transnational Neofascism in France and Italy (Cambridge, Eng., 2015).

11. Such an approach is common in most edited collections on far right. See, e.g.: Andrea Mammone, Emmanuel Godin and Brian Jenkins eds., Mapping the Extreme Right in Contemporary Europe: From Local to Transnational (London, 2012); Sabine von Mering and Timothy McCarty, eds., Right-wing Radicalism Today: Perspectives from Europe and the US (London, 2013); Ruth Wodak, Majid Khosravinik and Brigitte Mral eds., Right-Wing Populism in Europe: Politics and Discourse (London, 2013).

12. For analyses of internet, see Manuela Caiani and Patricia Kröll, "The Transnationalization of the Extreme Right and the Use of the Internet," International Journal of Comparative and Applied Criminal Justice 39, no. 4 (October 2015): 331-51. For a very interesting example on symbolic and discursive borrowing, see Nicole Doerr, "Bridging Language Barriers, Bonding against Immigrants: A Visual Case Study of Transnational Network Publics Created by Far-right Activists in Europe,” Discourse and Society 28, no. 1 (January 2017): 3-23.

13. Clavin, “Defining transnationalism,” 422. 
I believe that this seemingly simple observation is relevant for our attempts to understand the transnationalization of the far right; it is by focusing on actors engaged in cross-border networks and communication that we can better understand the motivations behind the decisions to reach for partners/interlocutors in different countries. Given that far-right parties and movements persistently emphasize different sorts of "hands-onapproaches"-work that their own local communities (nations) are supposed to benefit from-it is necessary to probe deeper into the specific reasons for and outcomes of transnational cooperation. It is about learning from each other, exchanging toolkits, and borrowing certain ideological aspects, in short: various practices which are meant to make one's own organization or movement more successful. However, such practices presumably characterize most transnational organizations and movements; what remains to be investigated is what is specific about the operational methods of the far right on a transnational scale. Certainly, such an investigation should also consider asking if there is anything unique about far-right transnational contacts, which seems to me an important move against "othering” far-right activists, as discussed below.

To some, the far right's networks' specificity lies in the fact that nationalism (which most extreme right groups exhibit in some form) is by definition exclusive, therefore making the idea of "transnational nationalism" oxymoronic. Consequently, such cooperation is described, at best, as something astonishing and contradicting. Often, however, scholars actually dismiss it or argue that "fascist internationalism was merely a camouflage and a sham," as Arnd Bauernkämper critically observes in the context of his historical research. ${ }^{14}$ Nonetheless, it seems reasonable to ask: is transnationalization of nationalism indeed so surprising or unthinkable if we consider the roots of nationalist ideologies in the $18^{\text {th }}$ and $19^{\text {th }}$ centuries and the way they were spread? This observation brings us back to the question of actorsnationalist ideologues and agents of nationalism, their mutual influences and interactions, which meant simultaneous attempts to distinguish and imitate, constrain or empower each other. At the same time, a careful focus on networking encourages us also to consider its limits, identifying moments in which "nationalism" wins out over the perceived benefits of "transnational" cooperation. Despite claims of a growing "league of nationalists" in today's Europe (and beyond), it is easy to notice that "access" to this league may be actually limited or restricted to some groups; this is often caused by historical legacies, in the main national(ist) memories of past conflicts which continuous to preclude cooperation. A reflection on the historical context leads to my second point.

14. Arnd Bauernkämper, "Interwar Fascism in Europe and Beyond: Toward a Transnational Radical Right," in Martin Durham and Margaret Power, eds., New Perspectives on the Transnational Right, (New York, 2010), 40. See also: Jessica Reinisch, "Introduction: Agents of Internationalism," Contemporary European History 25, no. 2 (May 2016): 195-205. 


\section{Taking Interdisciplinarity Seriously}

The previously articulated notion that "transnationalism" is the exploration of extreme right's cooperation beyond borders is underscored in importance once we recognize that connectedness and mutual influences are not recent phenomena limited to the recent wave of globalization. ${ }^{15}$ Numerous far-right nationalist movements, at least as far back as the early $20^{\text {th }}$ century, developed close relations, emulated and supported each other, despite often exclusive aims. As a matter of fact, it is precisely the investigation of the constant balancing and negotiations between "extra-" and "intra-" tendencies within nationalist activities and thought now and then that constitutes one of the most promising research avenues. Recent historical works on the subject discussing, for instance, Ukrainian-Croatian, Italian-Croatian and MacedonianCroatian exchanges of tools, tactics, and/or knowledge both contribute to a large body of literature on European fascisms in the 1920s and 1930s and go beyond it, exploring various aspects of those exchanges (which I identified above as crucial for current studies, too). The question of "borrowing," not only on the right but also on the left, includes problems of asymmetries and selective appropriation, as well as the issue of cooperation limits. ${ }^{16}$ It shows that nationalist activists of the interwar era collaborated, exchanging ideas and means of action, and were convinced about the need to establish a "nationalist internationalism" against "the international of gold and of Moscow." 17 Their slogans and calls for action resemble those that the far right today exchanges via social media and exposes during demonstrations: the importance of Christian heritage, patriarchal culture, national economies, and nation-states' integrity, while denouncing Judeo-Bolsheviks, capitalists, (neo)liberalism, and "global order."

There are multiple arguments in favor of a careful historical contextualization if one observes the present-day far-right scene: it is easy to note numerous cultural, aesthetic, and linguistic borrowings from the interwar

15. Such an argument is put forward for example by Thomas Grumke, "Globalized antiglobalists: The Ideological Basis of the Internationalization of Right-wing Extremism,” in Sabine Von Mering and Timothy McCarty, eds., Right-Wing Radicalism Today: Perspectives from Europe and the US, (Abingdon, Oxon, 2013), 13-21. What is also problematic about such approaches is a simplifying view of globalization as "frightening" and its enemies (far-right supporters) as emotionally responding to the threat of losing identity and traditions.

16. On Ukrainian-Croatian cooperation, see: Grzegorz Motyka, Wołyń '43: Ludobójcza czystka - fakty, analogie, polityka historyczna (Krakow, 2016); on Italian-Croatian cooperation, see Rory Yeomans, "The Adventures of an Ustasha Youth Leader in the Adriatic: Transnational Fascism and the Travel Polemics of Dragutin Gjurić," Journal of Tourism History 6, no. 2/3 (August-November 2015): 158-173; on Moldavian-Croatian, see: Oliver Schmitt, “'Balkan-Wien'-Versuch einer Verflechtungsgeschichte der politischen Emigration aus den Balkanländern im Wien der Zwischenkriegszeit (1918-1934),” SüdostForschungen 73, no. 1 (2016): 268-305.

17. Quote from the speech by Hungarian fascist Gyula Julius Gömbös (1919), in Nicholas M. Nagy-Talavera, The Green Shirts and the Others: A History of Fascism in Hungary and Romania (Iasi, Romania, 2001). "Moscow" in this quote stands for bolshevism, and as such it resembles anti-communist stands of present-day far right, who, while opposing communist, are not necessarily anti-Russian even as some of them actively cooperate with Russian far right. 
and World War II era. Whether you look at a poster inviting viewers to join a rally in Poland, or examine the font used in the inscription on a monument in Hungary, or read a political manifesto written by an Italian group, more or less conscious references to various interwar predecessors appear quite clearly. At the same time, this very rich source of references is also an extremely moldable one, and can be easily appropriated for other means: recall, for instance, the widely-shared photoshopped pictures of Angela Merkel wearing a Nazi uniform..$^{18}$ Meant to discredit opponents, the general use (or rather abuse) of notions of "fascism" and "Nazism" by all sorts of political activists illustrates well the different ways in which "history" features in present-day discussions. The different ways in which these terms are currently being used should also be an alert for researchers.

Recent successes of right-wing populist parties, notably the victory of US presidential candidate Donald Trump, saw numerous publications on the return to the "1930s."19 A question regarding the similarities between the present-day and the political-economic context that gave rise to far-right radicalism in post-World War I Europe is no doubt a meaningful one; the then economic crisis, unemployment among the middle and working classes, and waves of refugees across Europe no doubt exacerbated anti-Semitic and anticommunist rhetoric and the discourse of historical injustices. Similar developments can be observed today. ${ }^{20}$ Nonetheless, some comparisons with the 1930s often seem a bit rushed and not clear about what they mean to offer: analytical models, tools for understanding favorable conditions for populism, or simply facts regarding the long roots of a phenomenon that often seems to be a product of the recent wave of globalization? All these can be productive approaches, provided that we are explicit about the ways in which we use history: recognizing when it is a resource for scholars, enabling us to search for certain patterns and tendencies and, subsequently, discuss larger issues of radicalization, protest, and societal transformations. We use it to make sense of the actors we study, focusing on how they use history by mobilizing, manipulating, and adopting certain narratives and facts for their current needs.

When talking about entering into dialogue with different disciplines, such as history, I believe more attention needs to be paid to the terms we "borrow" and use when discussing socio-political developments. For instance, what seems to escapes attention in many recent discussions on whether Trump,

18. Such pictures were exposed, for instance, during anti-refugee demonstrations. See Fergal Keane, "Migrant Crisis: Is Germany Far Right Rise Echo of the Past," $B B C$, December 19, 2015, at www.bbc.com/news/world-europe-35124118 (last accessed May 2, 2017).

19. Such articles began appearing long before he was elected (See Bret Stephens, "The Return of the 1930s," The Wall Street Journal, March 7, 2016, at www.wsj.com/articles/ the-return-of-the-1930s-1457396236 (last accessed May 2, 2017); Paul Mason, "Are We Living through Another 1930s?," The Guardian, August 1, 2016, at www.theguardian. com/commentisfree/2016/aug/01/are-we-living-through-another-1930s-paul-mason (last accessed May 2, 2017).

20. It is sometimes observed that anti-Islamism replaced anti-Semitism, but I would argue that it rather supplemented anti-Semitic discourses, contributing to a discussion about the enemies of Christianity. 
Orban, or le Pen can be described as "fascist" is a simple recognition that "fascism" can been defined and understood in multiple ways. Consequently, adopting the term without clarifying what is meant by "fascism" or providing a specific reference might well hinder rather than foster a more sophisticated analysis of phenomena and actors at hand. ${ }^{21}$ What goes in hand with such labeling is a lack of recognition that-no matter how wrong or disastrous from the liberal point of view-the various interwar fascist ideologies did contain a coherent theory of state and society, which makes questionable certain current attempts to "simply" label as (neo) fascist any movement that contains xenophobia, racism, hooliganism, or hate speech. ${ }^{22}$

Many other examples illustrating a blurred conceptual landscape could follow; notions of "authoritarianism," "populism," "illiberal governance," and the "far right" are sometimes used interchangeably, as if they related to the same set of phenomena. "Populism" itself is, as Jan Werner-Müller convincingly demonstrates in a recent book, a term loaded with numerous unfortunate connotations and misunderstandings and actually lacks a clear definition. ${ }^{23}$ Certainly, this conceptual sloppiness is at least in part due to the immense variety of those at the far-right, which makes finding adequate terms difficult and forces us to recognize that the extreme right today-both at the level of political parties and more informal networks-includes anti-elitist activists and "elitist populists," self-declared neo-fascists/neo-Nazis and those consciously rejecting such ideological affinities/legacies, and, last but not least, actors monopolizing both the right-wing and left-wing agenda. ${ }^{24}$ My own use of the notion of far right throughout this text is indeed far from ideal. ${ }^{25}$

21. See Robert Kagan, "This is How Fascism Comes to America," The Washington Post, May 18, 2016, at www.washingtonpost.com/opinions/this-is-how-fascism-comesto-america/2016/05/17/c4e32c58-1c47-11e6-8c7b-6931e66333e7_story.html?utm_term=. d0c30f228288 (last accessed May 2, 2017); Owen Jones, "Hungary’s Chilling Plight Could Foreshadow Europe's Future,” The Guardian, October 13, 2016, at www.theguardian. com/commentisfree/2016/oct/13/hungary-future-europe-far-right-viktor-orban (last accessed May 2, 2017); John Lichfield, "Why We Should Be Scared of Marine Le Pen's Front National,” The Independent, December 8, 2015, at www.independent.co.uk/news/ world/europe/why-we-should-be-scared-of-marine-le-pens-front-national-a6765751.html (last accessed May 2, 2017). For a critical take on such comparisons, see: Dirk Kurbjuweit, "How Much Mussolini Is There in Donald Trump?,” Spiegel Online, November 24, 2016 at www.spiegel.de/international/zeitgeist/can-donald-trump-be-called-a-fascist-a-1122035. html (last accessed May 2, 2017).

22. A. James Gregor, The Search for Neofascism: The Use and Abuse of Social Science (Cambridge, Eng., 2006), 15-16.

23. Jan-Werner Müller, What is Populism? (Philadelphia, 2016).

24. Which does not mean that their discourses and practices do not bear resemblances to some fascist ideas.

25. For a discussion on terminology and classifications, see: Kathleen Blee and Kimberly Creasap, “Conservative and Right-Wing Movements,” Annual Review of Sociology 36 (2010): 269-86; Manuela Caiani and Donatella Della Porta, "The elitist populism of the extreme right: A frame Analysis of Extreme Right-wing Discourses in Italy and Germany," Acta Politica 46, no. 2 (April 2011): 180-202; Michael Minkenberg, "The Renewal of the Radical Right: Between Modernity and Anti-modernity," Government and Opposition 35, no. 2 (Spring 2000): 170-88; Kristen Ghodsee, "Left Wing, Right Wing, Everything: Xenophobia, Neo-totalitarianism and Populist Politics in Bulgaria," Problems of PostCommunism, 55, no. 3 (May/June 2008): 26-39. 
In emphasizing this diversity, I do not mean to question the necessity of, however imperfect or limiting, concepts which are indispensable to navigate the increasingly complex reality around us. These considerations are simply meant as a call for a thoroughly understood interdisciplinarity: as a serious reflection on what an exchange of methodologies, theoretical outlooks, and conceptual tools may offer and as a reminder that these perspectives and concepts are strongly rooted in specific disciplinary traditions, making certain terms and definitions more "mobile" or "adoptable" than others; and that these terms vary from highly abstract notions to emic terms used by social actors.

\section{Taking Research Participants Seriously}

The discussion on transnationalism and interdisciplinarity as features of current research on the far right has a common denominator in the form of a call for a more thoughtful analysis of the social actors, no matter if this means a focus on far-right militants, right-wing populists, or their voters. This discussion would not be complete without a reflection on the ethical aspects of a study of far-right activists, people we are likely to think of as inhabiting the opposite end of the political (and perhaps moral) spectrum from ourselves. Such a reflection means asking how should we study those we disagree with and what is the place of such studies within anthropology and kindred social sciences? One could assume that far-right activists are, in anthropologists' eyes, "repugnant others," the people an anthropologist could hardly empathize with. ${ }^{26}$ Recent political developments, however, brought out voices from left-leaning scholars and opinion-makers that highlight the radical left's and right's "common cause," and depict far-right followers as poor and misled victims of the neoliberal system; people who are "angry," or whose decisions are caused by "fear." While in theory attempting to be "emphatic," in practice not only are such approaches often extremely patronizing, but they also constitute a self-congratulatory narrative. Whether by describing far-right voters as emotional and describing "us," the conscious part of society, as following rational logic, or by constructing an image of right-wing activists as criminal delinquents, such narratives end up reinforcing the idea of far-right actors as the "others" of society. ${ }^{27}$

Finding a more productive approach relies, in my view, on two premises, both of which are hinted upon, yet not explicitly spelled out, in the latest anthropological literature. One of them is the recognition that in a world that is so deeply interconnected "it became epistemologically and morally difficult to place 'the others' on a different moral scale than oneself." ${ }^{28}$ However, in providing examples of "others," scholars tend to mention those individuals

26. Susan Harding, "Representing Fundamentalism: The Problem of the Repugnant Cultural Other," Social Research 58, no. 2 (Summer 1991): 373-393.

27. On far-right supporters as emotional, see Müller, What is Populism?, 16; on far-right activists as delinquents, see Nitzan Shoshan, The Management of Hate: Nation, Affect, and the Governance of Right-wing Extremism in Germany (Princeton, 2016).

28. Thomas H. Eriksen, “Overheating: The World Since 1991," History and Anthropology 27, no. 5 (December 2016): 469-87. 
and communities, "people on the margins," that anthropologists (and other scholars) may easily sympathize with, leaving aside the question of how to study people who occupy the opposite side of the political spectrum and who perhaps, simultaneously, also occupy "the margins." ${ }^{29}$ If the first step is questioning different moral scales, then the second one should consist of reflecting on why "the margins" tend to be occupied by politically-sympathetic "oppressed" people, and of rethinking the meaning of empathy, which is often a path to the (!) "populist syndrome." ${ }^{30}$ An interdisciplinary perspective can be of big help here, too. ${ }^{31}$

Although some might object to situating the far right on the margins (and support their claims with recent opinion polls and electoral results), the idea of "margins" as I understand it here is meant more broadly and refers to various public representations of far-right supporters in public discourses. As some anthropological takes on common explanations of anti-refugee sentiments in postsocialist countries show, empathy does not need to equal pity, and an attempt to recognize the complex reasons behind far-right success does not need to equal highly problematic patronizing approaches towards the "fear-full" (and "fearful") citizens I mentioned above..$^{32}$ On the contrary, it indicates a need to grant or restore agency to far-right propagators/supporters, which means taking into account that their views on homosexuality, religion, or the shape of nation-states are their ways of engaging with and changing the world. Anthropologists have long argued against notions of false consciousness and mystification, highlighting the multidimensionality of agency and resistance. It seems continuously hard to accept that the results of agency and resistance are not always what we would like to see.

This is no doubt a demanding and challenging ethical stand, yet necessary if we want to contribute to a better understanding of the effectiveness of far-right strategies, including the motivations behind joining the ranks of right-wing extremists and the reasons for extremism's populist appeal. From an anthropological perspective, the importance of which I have tried to advocate in this article, it no doubt appears challenging but certainly in line with what scholars pursuing ethnography-based studies have been trying to achieve for decades by focusing on people's own understanding of their

29. For example, in Eriksen, “Overheating,” 479-80, Eriksen suggests: “. . . cultural relativism can no longer be an excuse for not engaging existentially with the victims of patriarchal violence in India, human right lawyers in African prisons, minorities demanding not just cultural survival but fair representation in their governments."

30. See: Harding, "Representing Fundamentalism"; Christian Giordano, "I Can Describe Those I Don't Like Better than Those I Do: 'Verstehen' as a Methodological Principle in Anthropology,” Anthropological Journal on European Cultures 7, no. 1 (1998): 27-41. According to Giordano, the "populist syndrome" manifests in the studies of discriminated groups with whom anthropologists empathize and (over)identify.

31. See, for example, Kathleen Blee, "Evidence, Empathy and Ethics: Lessons from Oral Histories of the Klan," Journal of American History, 80, no. 2 (September 1993): 596-606. Blee engages with oral history's method of "romantic assumptions" about the subjects of history from the bottom and, drawing on her own research experiences, discusses certain unexpected dilemmas of research on racism.

32. Chris Hann, "The Fragility of Europe's Willkommenskultur," Anthropology Today 31, no. 6 (December 2015): 1-2. 
lived realities, concerns, and aspirations. To some, results of a more thorough research on the far right-methodologically, conceptually, and ethically-may be far from "comforting" in that they will question some of the assumptions that served us on an everyday basis in the form of stories of cosmopolitan cities and peripheral backwardness, enlightened elites and intolerant everymen. Yet this indicates even more a need for an approach I strove to advocate: its importance lies not only in its potential contribution to scholarship but in bringing about a societal/political change, and more specifically in preventing building more walls, including physical ones envisioned by some current political leaders, and those that many more people contribute to that are aptly described by Arlie Hochschild as "empathy walls." 33

33. Arlie R. Hochschild, Strangers in Their Own Land: Anger and Mourning on the American Right (New York, 2016). 